This item was submitted to Loughborough's Research Repository by the author.

Items in Figshare are protected by copyright, with all rights reserved, unless otherwise indicated.

\title{
Thermal shockwaves in an upland river
}

\section{PLEASE CITE THE PUBLISHED VERSION}

http://dx.doi.org/10.1002/wea.2435

\section{PUBLISHER}

Wiley / @ Royal Meteorological Society

\section{VERSION}

AM (Accepted Manuscript)

\section{PUBLISHER STATEMENT}

This work is made available according to the conditions of the Creative Commons Attribution-NonCommercialNoDerivatives 4.0 International (CC BY-NC-ND 4.0) licence. Full details of this licence are available at: https://creativecommons.org/licenses/by-nc-nd/4.0/

\section{LICENCE}

CC BY-NC-ND 4.0

\section{REPOSITORY RECORD}

Wilby, Robert L., Matthew F. Johnson, and Julia Toone. 2019. "Thermal Shockwaves in an Upland River". figshare. https://hdl.handle.net/2134/17682. 


\section{Thermal shockwaves in an upland river}

2

3 Robert L. Wilby ${ }^{1}$, Matthew F. Johnson ${ }^{1}$ and Julia A. Toone ${ }^{2}$

$4 \quad{ }^{1}$ Department of Geography, Loughborough University, Loughborough, Leicestershire, LE11 3TU, UK

$5 \quad{ }^{2}$ Environment Agency, Trentside Office, Nottingham, NG2 5FA, UK

6

7

8

9 Accepted for publication: Weather

10 Date of acceptance: 11 August 2014

11

12

13

14 Corresponding author:

15 Robert L Wilby

16 Department of Geography

17 Loughborough University

18 Loughborough

19 Leicestershire

20 LE11 3TU, UK

21

22 Email: r.l.wilby@lboro.ac.uk

23 Tel: +44 1509223093 


\section{Abstract}

We investigate the genesis and propagation of thermal 'shockwaves' using one of the densest arrays of paired air-water thermistors in the UK. Three onset mechanisms were detected in the River Dove driven by: solar radiation under stable flow and clear skies; rapid cooling by snowmelt; or runoff from intense summer rainfall. Largest absolute temperature changes were solar driven, but greatest rates of change (+3 degC in 15 minutes) were triggered by summer storms. These shockwaves travel downstream at lower velocities than hydropeaks. Climate models project more extreme rainfall so thermopeaks could exert greater influence on freshwater taxa in the future.

Key words: Water temperature; solar radiation; summer rainstorm; thermopeak; River Dove

\section{Introduction}

River temperature (Tw) is a fundamental determinant of water quality, chemical rates, biological processes, and organism behaviour (Webb et al., 2008). As such, there is concern that rising Tw and changing patterns of river flow under anthropogenic climate change could adversely impact freshwaters (Caissie, 2006; Orr et al., 2014). Hence, there are calls for active management of surface/groundwater flows and riparian vegetation to safeguard cool refugia and vulnerable species (Hansen et al., 2003). At the same time it is recognised that such interventions should be founded on process-understanding obtained through field observation and modelling (Wilby et al., 2010).

Field studies of the energy fluxes controlling Tw show that approximately $70 \%$ of heat input originates from solar radiation, with the remainder provided mainly by friction of water with the river bed and banks, and sensible heat transfer from the atmosphere (Webb et al., 2008). Air temperature (Ta) is widely used as a surrogate for solar radiation in empirical models for predicting Tw variations over time-scales of days to months (Johnson et al., 2014). The most significant heat outputs are radiation, evaporation, bed conduction and sensible heat transfer across the water-air interface. Local factors such as landscape shading, river orientation and vegetation cover affect receipts of solar radiation; groundwater fed streams may have increased longwave, latent and sensible heat losses (in winter); channel morphology, river flow and artificial structures influence heat advection from upstream. Global mean annual Tw 
is approximately 14 degC but there are large regional variations. Maximum Tw can reach 35 degC in equatorial, arid and warm temperate climate zones, however, mean Tw varies between $4 \operatorname{deg} \mathrm{C}$ and $27 \operatorname{deg} \mathrm{C}$ in polar and equatorial regions respectively (Punzet et al., 2012).

We deploy a high resolution thermistor array to investigate rapid Tw variations linked to weather conditions. We favour these instruments because of their low cost and accuracy which enable detailed sampling of Tw in space and time. Alternatives such as airborne remote sensing can yield high quality information on spatial patterns of surface Tw but only for snapshots in time and where the river is not obscured (Torgersen et al., 2001). Conversely, site-specific monitoring of heat budget components provides detail on temporal variations in Tw but is less feasible for large numbers of locations (Webb et al., 2008). Fibre optic methods offer high spatial and temporal resolution but only over distances of up to several kilometres (Krause et al., 2013).

Here, we focus on acute as opposed to chronic Tw changes because of their potential for sudden onset and significant ecosystem impacts (Beaulieu et al., 2013; Bruno et al., 2013; McHenry and Long, 1995). Rapid Tw increases (thermopeaks) have been reported under a range of artificial conditions including thermal discharges from power stations (Langford and Aston, 1972); warm water releases in winter (Dickson et al., 2012; Webb, 1995) and cool water in late spring/summer (Zolezzi et al., 2011) from hydropower reservoirs; as well as warm runoff from summer storms over paved surfaces (Herb et al., 2008; Sabouri et al., 2013).

Natural causes of rapid Tw reductions have also been documented. For example, Smith and Lavis (1975) describe decreases in Tw associated with individual rainfall and snowmelt events. Maybeck (2004) also recounts how a summer thunderstorm released sufficient cool water into the Pemigewasset River, New Hampshire for Tw to fall by 7 degC within six hours. Similarly, Gammons et al. (2005) note a modest Tw reduction associated with a hail storm in Butte Montana, US and Lange and Haensler (2012) observed significant drops in Tw when post-drought storm runoff was dominated by event water in the Black Forest, Germany.

Conversely, Langan et al. (2001) assert that the thermal impact of storm events is seasonally dependent and can yield Tw increases when heat is advected from riparian wetlands. Subehi et al. (2010) show the importance of hillslope gradient and water table depth in determining the hydrological pathway (i.e., relative mix of surface/sub-surface runoff) and hence Tw 
response to rainfall in small forested catchments. Brown and Hannah (2007) found that shortduration low-intensity storms falling onto an alpine catchment can occasionally produce Tw increases of up to 2.3 degC.

From the above synopsis it is evident that meteorological controls of river temperature responses are mediated by antecedent river flow and catchment conditions (such as soil temperature and moisture content), type of land cover, topography, contributions from groundwater, attributes of the generating event, and so forth. The purpose of this study is to use a high-resolution thermistor array to 1) establish a typology of rapid, sub-daily Tw changes; and 2) present empirical evidence of the magnitude of Tw change, rate of downstream propagation and dispersion of these short-lived phenomena. The ultimate aim of the research is to improve understanding of the drivers and raise awareness of the potential significance of thermal 'shockwaves' for temperate river ecosystems.

\section{Study area, data and methods}

The study catchment and field experiments are described by Wilby et al. (2012), Johnson et al. (2014) and online at http://www.luten.org.uk. The Loughborough University TEmperature Network (LUTEN) comprises 36 sites with synchronised Tw and Ta measurements in the rivers Dove and Manifold of the English Peak District (Figure 1). Pasture is the main landuse in both catchments and elevations range from 150 to $450 \mathrm{~m}$. This study employs a sub-set of the data collected in the Dove catchment (sites D1 to D23) which is fed largely by groundwater seepage plus flows from non-thermal and semi-thermal springs along the margin of the Limestone outcrop (Edmunds, 1971). These sources discharge at relatively constant temperatures year-round thereby lowering ambient $\mathrm{Tw}$ in summer but increasing $\mathrm{Tw}$ in winter (Johnson et al., 2014). Parts of the headwaters and lowest reaches of the Dove are in deep landscape shade, whereas middle sections are most exposed to direct solar radiation.

Two Gemini Tinytag Aquatic 2 thermistors record maximum, mean and minimum temperatures every 15-minutes at each site: one on the river bed measuring Tw; the other at about $2 \mathrm{~m}$ above the water surface measuring Ta. Tinytag sensors have a quoted accuracy of 0.2 degC which we checked under field and laboratory conditions (Johnson and Wilby, 2013). To avoid heating by direct solar radiation sensors were fixed in deep shade. Data reported here are for three years March 2011 to February 2014. 
117 Fifteen-minute river flow data were acquired from two gauges kept by the Environment

118 Agency (EA). The Hollinsclough (HC) gauge is in the upper Dove and has a drainage area of

$1198 \mathrm{~km}^{2}$; the Izaak Walton (IW) gauge is downstream and represents a catchment of $83 \mathrm{~km}^{2}$

120 (Figure 1). According to the National River Flow Archive both river flow records are defined

121 as 'natural to within $10 \%$ at the 95th percentile' (although for HC river flow estimates $>0.8$

$122 \mathrm{~m}^{3} \mathrm{~s}^{-1}$ are based on rating tables and should be treated with caution). Note also that there are

123 more than 100 shallow weirs and occasional sub-surface field drains in the lower reaches of

124 the Dove (between D17 and D24).

125 Daily precipitation totals were acquired from UK Met Office stations at Buxton (53'15’ N, $\left.1261^{\circ} 55^{\prime} \mathrm{W}\right)$ and Ashbourne $\left(53^{\circ} 1^{\prime} \mathrm{N}, 1^{\circ} 44^{\prime} \mathrm{W}\right)$. These lie $\sim 10 \mathrm{~km}$ to the north of the source and south of Dovedale (D24) respectively. Hourly precipitation data were obtained from stations

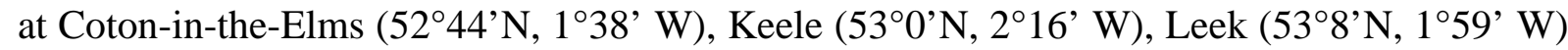
and Hollinsclough ( $53^{\circ} 12^{\prime} \mathrm{N}, 1^{\circ} 54^{\prime} \mathrm{W}$ ) within the headwaters of the Dove.

We objectively identified thermopeaks using the rate of change (ROC) of Tw over one hour at site D10 (Figure 1). We did not discriminate between rising or falling limbs but only take note of the most extreme value (whether positive or negative) each day. We then ranked all days and extracted the 12 largest absolute ROC along with antecedent precipitation total, air temperature (at D10) and concurrent river flow in each case. Site D10 was chosen because of its central location within the catchment (above the Limestone gorge) and because the record is $97 \%$ complete. Moreover, the Tw series at D10 is most highly correlated (average r=0.98) with all other sites in the Dove, so is regarded to be representative.

Finally, we estimate thermal and flood (or hydrodynamic) wave velocities with the expectation that they are asynchronous. This is because the thermal peak behaves as a passive tracer and is advected downstream at the velocity of water molecules depending on river flow depth and channel roughness. This advective heat transport is further influenced by local heat exchange with the stream bed, hyporheic exchange or storage within in-stream 'dead-zones' (Evans et al. 1998, Neilson et al. 2010, Westhoff et al. 2010; 2011). Meanwhile, the flood wave travels more quickly than water molecules with the velocity depending on free surface width, volume and depth of flow relative to pre-event conditions (Toffolon et al., 2010).

146 If the thermal wave was triggered by a storm, event initiation was assumed to be the time of 147 peak rainfall intensity measured at Hollinsclough (the closest gauge). Downstream variations 148 in thermal wave velocity were then determined using distance between sites and time of 
149 arrival of peak Tw. Velocities for hydrodynamic waves were estimated using the known

150 distance between HC and IW (27.9 km) and the difference in time of arrival of the

151 hydrograph peak at each gauge to the nearest 15 minutes.

152

\section{Results}

154 Our three year monitoring period included several notable hydrological events. For example, spring 2011 had the most severe and widespread April snow storm since 1981. Violent storms in late June and early July 2012 brought flash flooding across numerous locations in England and Wales (Almond, 2013; Clark and Webb, 2013). These episodes also contributed to the wettest April to July in nearly 250 years and brought an abrupt end to one of the most significant prolonged droughts in a century (Kendon et al., 2013; Parry et al., 2013). The first week of May 2013 was notable for the amount of bright sunshine which reached 14 hours on some days. Winter 2013/14 was confirmed as the wettest since 1766 in the England and

162 Wales precipitation series, with more than 130\% average rainfall locally in the Peak District 163 (Met Office, 2014).

164 Figure 2 shows the ROC trace for site D10 in 2012/13. This series is strongly correlated 165 ( $r=0.9)$ with ROC data up and downstream (sites D6 and D16 respectively). ROC values 166 seldom exceed \pm 1 degC/hour so events with rapid Tw change clearly stand out (as in the case of 4 April 2012, 28 June 2012, 5 July 2012 and 27 January 2013). Across the three years of data, the 12 largest ROC scores all exceeded \pm 0.8 degC/hour at D10 (Table 1). Overall, the most extreme ROC (15 minute) for any site was +3 degC recorded at site D1 between 2030 UTC and 2045 UTC on 5 July 2012.

171 Three types of event were distinguished by inspection of the full data set (Table 1). Overall,

172 the most rapid positive Tw changes were preceded by intense rainfall (IR); the two most

173 extreme negative ROCs were linked to heavy snowfall and/or melt (SM). The remaining

174 events occurred on days with zero precipitation, stable or falling river flow, and large diel Ta 175 ranges (typically $>17$ degC). These events were all preceded by nocturnal cooling then by 176 intense solar heating ( $\mathrm{SH}$ ) under clear sky conditions. The most extreme ROC (per hour) at $177 \mathrm{D} 10$ for each category of event was $+2.8 \operatorname{deg} C$ for $I R,-1.3 \operatorname{deg} C$ for $S M$, and $+1.2 \operatorname{deg}$ C for 178 SH (Table 1). 
Figure 3 shows examples of the downstream propagation of thermal waves generated by these three mechanisms. Under intense $S H$ events, Tw increases most rapidly between midmorning and mid-afternoon at upstream sites. The thermal wave is modified by heat exchanges between atmosphere and river as it advects downstream, typically arriving at sites above the spring line (D16) between 1700 UTC and 2000 UTC (Figure 3a). The magnitude of the diel Tw range depends on the volume of flow (i.e., thermal inertia of the water body), strength of solar shortwave radiation, net longwave radiation, convection, and evaporation heat fluxes (Evans et al., 1998). The damped response of Tw between D16 and D23 shows that groundwater inputs reduce the diel range even when there is strong radiant forcing upstream.

Under SM events (such as 4 April 2012) relatively cold water enters the drainage network either directly as precipitation or indirectly as melt-water from ablating snow cover. The thermal sag drifts downstream such that absolute Tw minima experienced at downstream sites occur hours after detection in the headwaters (Figure 3b). Again, the markedly different Tw behaviour at D23 compared with upstream reflects the input of relatively warm groundwater. The thermal constancy of spring sources is evidenced by the similarity of the signal for D23 under SH and SM forcing (Figures 3a and 3b).

The most dramatic thermal response occurs after $I R$ events (Figures 3c and 3d). The exact shape of the thermopeak depends on the attributes of the generating storm (duration, maximum intensity, and direction of travel relative to the main channel orientation). The thermal wave on 28 June 2012 (Figure 3c) was initiated by an intense storm with maximum precipitation rate $>13 \mathrm{~mm} /$ hour at Hollinsclough (Figure 4a). The hydrograph response at the upstream gauge was subdued compared with downstream reflecting the SW to NE passage of the frontal system and zone of maximum rainfall intensity which was located to the south.

The peak rainfall intensity on 5-6 July 2012 was lower ( 9 mm/hour) than on 28 June 2012 (Figure 4a and 4b) but a greater total fell onto ground that was already saturated (as indicated by the higher initial river flows in Table 1). Storm onset was marked by a rapid drop in Ta and near immediate rise in river flow at the HC gauge (Figure 3d). Coincident thermal peaks at D1 and D16 may indicate earlier arrival of a local rainstorm at the downstream site. An alternative explanation is that runoff from paved surfaces in the hamlet of Mill Dale added warm water to the river between D16 and D20. The spring site (D23) exhibited a damped but earlier than expected thermal response to both $I R$ events. This was attributed to a sub-surface 
211 field drain that discharges from the west-facing escarpment into the river between sites D22

212 and D23.

213 Consistent with theory, hydrodynamic wave velocities were higher than thermal wave

214 velocities as indicated by shorter travel times to fixed sites (Figure 5). Non-linear time-

215 distance relationships show that the thermal wave is decelerating. The most rapid

216 hydrodynamic wave followed high intensity rainfall over the whole catchment (28 June 2012)

217 whereas the most rapid thermal wave trailed lower intensity rainfall but relatively high totals

218 in the headwaters (5-6 July 2012). Hence, depending on the spatial-temporal dynamics of the

219 storm, the estimated travel time of the hydrodynamic wave between HC and IW varied

220 between 270 and 435 minutes (equivalent to $1.1-1.7 \mathrm{~ms}^{-1}$ ) compared with 619 to 951

221 minutes (or $0.5-0.8 \mathrm{~ms}^{-1}$ ) for the thermal wave.

222 The travel time analysis indicates that following IR events stream biota are exposed first to

223 rising river flow then second to a thermal shock. The separation time between the two waves

224 increases with distance from source. Under the most extreme case (28 June 2012) the

225 estimated time interval between arrival of the hydrodynamic and thermal waves at IW

226 was $>11$ hours. Furthermore, at sites above the spring zone, the duration of the event (as

227 indicated by the time for Tw to return to pre-event values) increases downstream due to

228 turbulent diffusion and shear flow dispersion. For example, the thermal wave on 28 June

2292012 increased Tw for 645 minutes at site D1 and 855 minutes at D10.

230 The following section considers the wider implications of these findings including the

231 potential significance of thermal waves for freshwater taxa.

\section{Discussion}

234 Based on data from LUTEN we have detected three mechanisms that can generate rapid

235 responses in river temperatures. These are heating by solar radiation under clear skies and

236 low flow conditions; cooling by direct snowfall and/or melt-water runoff; or heating by

237 runoff produced by intense summer storms. Heating by solar radiation typically yields

238 maximum Tw at downstream sites just after sunset (Figure 3a). However, a noteworthy

239 feature of $I R$ events is that abrupt changes and maximum Tw can occur during the night, at

240 times when Tw would otherwise be dominated by net radiant losses (Evans et al., 1998). 
Moreover, $I R$ events generate the most rapid sub-daily Tw changes: up to +3 degC in 15 minutes for the most extreme case (D1 on 5 July 2012).

243 These observations arise from a small sample of events that were identified objectively via 244 ROC values. In general, IR events are expected to be most severe when Ta > Tw, there has been strong solar heating of the land surface, the storm is intense, and initial river flow is low

246 (Herb et al., 2008). The three most extreme $I R$ events all occurred during a two week period 247 of remarkable transition from drought to flooding (Parry et al., 2013). However, additional 248 thermal waves emerge when the ROC threshold is relaxed to a threshold of \pm 0.5 degC/hour. 249 For example, following >60 mm rainfall at Buxton on 27 July 2013, a ROC of +0.6 250 degC/hour was recorded. Another event on 18 July 2011 was triggered by $>65 \mathrm{~mm}$ rainfall at 251 Leek which led to an abrupt increase in river flow and was marked by the arrival of warmer water from upstream of D23. This diluted the signature of cooler spring water and caused Tw to change +1.6 degC between 0400 UTC and 0415 UTC at D23 (Figure 6).

254 Primary and secondary $I R$ events in the Dove are generally associated with daily rainfall totals $>20 \mathrm{~mm}$ at Buxton. Analysis of records since year 1961 suggests that rainfall totals of this magnitude or more occur between zero to four times per summer (June to August). However, variations in the features of individual thermal waves are explained by several other factors operating in the Dove. First, abrupt heating or cooling is superimposed on diel and annual Tw regimes which are governed by seasonal variations in solar heating and river flow (Webb and Walling, 1985). Second, thermal wave propagation and longitudinal dispersion are affected by the extent of pre-heating and ponding behind the weirs between D16 and D23. Third, absence of tributaries limit scope for mixing of thermally contrasting water in the upper Dove, but this is not the case where field drains and springs feed into the lower reaches. Evidence of distinct thermopeaks in the main stem of the dendritic network of the river Manifold (not shown) implies that the influence of surface runoff from tributaries may not be significant in these small catchments.

We venture that $I R$ events may be generating thermal waves in other natural headwaters in the UK. For the Dove, the thermal wave amplitude was greatest $~ 10 \mathrm{~km}$ from source, dissipating thereafter even before encountering cooler groundwater. Hence, we speculate that catchments with areas $<100 \mathrm{~km}^{2}$ and flashy hydrological regimes might be particularly vulnerable (but scope for testing this hypothesis elsewhere is constrained by data availability). 
273 Other factors such as channel gradient, roughness, pool-riffle sequencing, connectivity to

274 floodplain, and artificial structures influence the local velocity of the thermal wave and

275 thereby space-time variations in heat budget. Land cover and soil moisture conditions

276 determine the fraction of solar energy partitioned into sensible heating of the surface prior to

277 storm onset. For instance, streams draining urbanised catchments are known to exhibit

278 thermo-peaking after strong solar heating and heavy rainfall (Herb et al., 2008; Sabouri et al.,

279 2013). Conversely, larger catchments have greater scope for turbulent diffusion and shear

280 flow dispersion with distance downstream. There may also be tributaries and groundwater units which mix thermally contrasting water into the main channel flow.

282 Abrupt changes in Tw are known to trigger a range of sub-lethal, biological responses. For

283 example, benthic invertebrates exhibit species- and season-dependent avoidance strategies under carefully controlled laboratory conditions (Carolli et al., 2012). Moreover, because of synergistic effects, asynchronous hydro- and thermo-peaks cause greater density of invertebrate movement than hydro- or thermo-peaks alone (Bruno et al., 2013). Due to increasing separation time between the two peaks with distance downstream a spatial signature in invertebrate response is expected. Tw is also an important behavioural cue for the timing of feeding in juvenile Atlantic salmon (Salmo salar) which occurs preferentially at night when Tw falls below 10 degC (Fraser et al. 1993). Hence, arrival of a thermal wave during hours of darkness may be particularly significant for nocturnal creatures (Wilby et al., 2014).

293 Climate model projections show increased likelihood of extreme rainfall linked to higher atmospheric temperatures and vapour content (Trenberth, 2011). On the other hand, a scenario of higher Ta implies that the frequency of snowfall in the UK could diminish. Under these conditions, occurrence of $I R$ events would be expected to increase, whereas $S M$ events could become rarer. However, the future magnitude and frequency of thermal waves also depends on the antecendent conditions of the receiving water course. Climate model outlooks for the UK are ambiguous for winter, but there is greater consensus that river flows could decrease in summer (Prudhomme et al., 2012). A hotter, drier summer climate, with lower flow volumes, would pre-dispose rivers to more frequent $S H$ and $I R$ events. One high resolution $(1.5 \mathrm{~km})$ climate model experiment suggests that the frequency of very heavy rainfall episodes in summer could nearly quadruple by 2100 (Kendon et al., 2014). 
306 We have evidence of the genesis and propagation of thermal waves in a 'natural' headwater

307 river. Three onset conditions were identified: bright sunshine, heavy snowfall/melt, or intense

308 summer rainfall. These phenomena matter because they potentially affect water quality and

309 produce sub-lethal behavioural responses in biota. Our results also demonstrate that thermal

310 waves can occur under meteorological conditions other than strong solar radiation. One

311 implication of this finding is that increased riparian shade is not a complete panacea for

312 warming rivers because it would afford little protection against storm generated Tw changes.

313 Further research is needed to determine whether abrupt Tw increases are occurring in other

314 catchments and the extent to which these phenomena are mediated by regional climate and

315 land surface properties. It is also unclear which taxa might be most sensitive to thermal waves

316 and the extent to which any trends in timing, magnitude and frequency of these events might

317 be detectable as changes in ecosystem structure and function. Some have begun to explore

318 such questions under laboratory conditions to mimic thermo-peaking below dams, but this

319 work is largely restricted to invertebrate behaviour. Whereas conventional (monthly, day-

320 time) spot-sampling of Tw may be barely sufficient for tracking environmental change over

321 decadal time-scales, this is clearly insufficient for discerning biologically relevant thermal

322 cues at storm-event scales.

323

\section{Acknowledgements}

325 The authors thank the landowners who kindly granted access to the field sites, the Met Office 326 for providing meteorological data, as well as the Wild Trout Trust and Trent Rivers Trust for 327 supporting the purchase of equipment. Data from the LUTEN network may be obtained from: 328 http://www.luten.org.uk/ or by contacting the authors. 


\section{References}

332 Almond C. 2013. Heavy rain and flooding in southwest England on 6-7 July 2012. Weather, 68: $171-175$.

334 Beaulieu JJ, Arango CP, Balz DA, Shuster WD. 2013. Continuous monitoring reveals 335 multiple controls on ecosystem metabolism in a suburban stream. Freshwater Biology, 58:

336 918-937.

337 Brown LE, Hannah DM. 2007. Alpine stream temperature response to storm events.

338 Journal of Hydrometeorology, 8: 952-967

339 Bruno MC, Siviglia A, Carolli M, Maiolini, B. 2013. Multiple drift responses of benthic 340 invertebrates to interacting hydropeaking and thermopeaking waves. Ecohydrology, 6: 511341522.

342 Caissie D. 2006. The thermal regime of rivers: a review. Freshwater Biology 51: 1389-1406.

343 Carolli M, Bruno MC, Siviglia A, Maiolini B. 2012. Responses of benthic invertebrates to 344 abrupt changes of temperature in flume simulations. River Research and Applications 28: 345 678-691.

346 Clark MR, Webb JDC. 2013. A severe hailstorm across the English Midlands on 28 June 347 2012. Weather, 68: 284-291.

348 Dickson NE, Carrivick JL, Brown LE. 2012. Flow regulation alters alpine river thermal 349 regimes. Journal of Hydrology, 464: 505-516.

350 Edmunds WM. 1971. Hydrogeochemistry of groundwaters in the Derbyshire Dome with 351 special reference to trace constituents. Report of the Institute of Geological Sciences, 71/7, 352 British Geological Survey, Keyworth.

353 Evans EC, McGregor G, Petts GE. 1998. River energy budgets with special reference to 354 river bed processes. Hydrological Processes 12: 575-595.

355 Fraser NHC, Metcalfe NB, Thorpe JE. 1993. Temperature-dependent switch between 356 diurnal and nocturnal foraging in Salmon. Proceedings of the Royal Society of London B 252: 357 135-139.

358 Gammons CG, Shope CL, Duaime TE. 2005. A 24 h investigation of the hydrochemistry 359 of baseflow and stormwater in an urban area impacted by mining: Butte, Montana.

360 Hydrological Processes, 19: 2737-2753.

361 Hansen LJ, Biringer JL, Hoffman JR (eds.) 2003. Buying time: a user's manual for 362 building resistance and resilience to climate change in natural systems. WWF Climate 363 Change Program, Berlin, Germany, 244pp. 
Herb WR, Janke B, Mohseni O, Stefan HG. 2008. Thermal pollution of streams by runoff from paved surfaces. Hydrological Processes, 22: 987-999.

366

367

368

369

370

371

372

373

374

375

376

377

378

379

380

381

382

383

384

385

386

387

388

389

390

391

392

393

394

395

396

397

398

Johnson MF, Wilby RL. 2013. Shield or not to shield: Effects of solar radiation on water temperature sensor accuracy. Water 5: 1622-1637.

Johnson MF, Wilby RL, Toone JA. 2014. Inferring air-water temperature relationships from river and catchment properties. Hydrological Processes, 28: 2912-2928.

Kendon EJ, Roberts NM, Fowler HJ, Roberts MJ, Chan SC, Senior CA. 2014. Heavier summer downpours with climate change revealed by weather forecast resolution model. Nature Climate Change, doi: 10.1038/NCLIMATE2258.

Kendon M, Marsh T, Parry S. 2013. The 2010-2012 drought in England and Wales. Weather, 68: 88-95.

Krause S, Taylor SL, Weatherill J, Haffenden A, Levy A, Cassidy NJ, Thomas PA. 2013. Fibre-optic distributed temperature sensing for characterizing the impacts of vegetation coverage on thermal patterns in woodlands. Ecohydrology, 6: 754-764.

Langan SJ, Johnston L, Donaghy MJ, Youngson AF, Hay DW, Soulsby C. 2001. Variation in river water temperatures in an upland stream over a 30- year period. Science of the Total Environment, 265: 195-2007.

Lange J, Haensler A. 2012. Runoff generation following a prolonged dry period. Journal of Hydrology, 464: 157-164.

Langford TE, Aston RJ. 1972. The ecology of some British rivers in relation to warm water discharges from power stations. Proceedings of the Royal Society London B, 180: 407-419.

Maybeck HF. 2004. Rapid river water temperature fluctuations. U.S. Geological Survey, Natural Streamflow Information Program. River Gage Station USGS \#01076500 Pemigewasset River at Plymouth, New Hampshire, US.

McHenry MJ, Long JH Jr. 1995. A rapid increase in water temperature alters the swimming performance of striped bass (Morone saxatilis). In: Blair, E.A. and Waldman, J.R. (eds.). Final Reports of the Tibor T. Polgar-Fellowship Program, Section V, pp1-18. Hudson River Foundation, New York, US.

Met Office. 2014. UK seasonal weather summary: winter 2013/2014. Weather, 69: 99.

Neilson BT, Chapra SC, Stevens DK, Bandaragoda C. 2010. Two-zone transient storage modeling using temperature and solute data with multiobjective calibration: 1 . Temperature. Water Resources Research, 46: W12520.

\section{Orr HG, Simpson GL, des Clers S, Watts G, Hughes M, Hannaford J, Dunbar MJ,} Laize CLR, Wilby RL, Battarbee RW, Evans R. 2014. Detecting changing river temperatures in England and Wales. Hydrological Processes, doi:10.1002/hyp.10181. 
399 Parry S, Marsh T, Kendon M. 2013. 2012: from drought to floods in England and Wales.

$400 \quad$ Weather, 68: 268-274.

401 Prudhomme C, Young A, Watts G, Haxton T, Crook S, Williamson J, Davies H, Dadson

402 S, Allen S. 2012. The drying up of Britain? A national estimate of changes in seasonal river

403 flows from 11 Regional Climate Model simulations. Hydrological Processes, 26: 1115-1118.

404 Punzet M, Vo $\beta$ F, Vo $\beta$ A, Teichert E, Bärlund I. 2012. A global approach to assess the

405 potential impact of climate change on stream water temperatures and related in-stream first

406 order decay rates. Journal of Hydrometeorology, 13: 1052-1065.

407 Sabouri F, Gharabaghi B, Mahboubi AA, McBean EE. 2013. Impervious surfaces and 408 sewer pipe effects on stormwater runoff temperature. Journal of Hydrology, 502: 10-17.

409 Smith K, Lavis ME. 1975. Environmental influences on the temperature of a small upland 410 stream. Oikos, 26: 228-236.

411 Subei L, Fukushima T, Onda Y, Mizugaki S, Gomi T, Kosugi K, Hiramatsu S, Kitahara 412 H, Kuraji K, Terajima T. 2010. Analysis of stream water temperature changes during 413 rainfall events in forested watersheds. Limnology, 11: 115-124.

414 Toffolon M, Siviglia A, Zolezzi G. 2010. Thermal wave dynamics in rivers affected by 415 hydropeaking. Water Resources Research, W08536.

416 Torgersen CE, Faux RN, McIntosh BA, Poage NJ, Norton DJ. 2001. Airborne thermal 417 remote sensing for water temperature assessment in rivers and streams. Remote Sensing of 418 Environment, 76: 386-398.

419 Trenberth KE. 2011. Changes in precipitation with climate change. Climate Research, 47: 420 123-138.

421 Webb BW. 1995. Regulation and thermal regime in a Devon river system. In: Foster, I.D.L., 422 Gurnell, A.M. and Webb, B.W. (Eds) Sediment and Water Quality in River Catchments. John 423 Wiley \& Sons, Chichester.

424 Webb BW, Walling DE. 1985. Temporal variation of river water temperatures in a Devon 425 river system. Hydrological Sciences Journal 30: 449-464.

426 Webb BW, Hannah DM, Moore RD, Brown LE, Nobilis F. 2008. Recent advances in 427 stream and river temperature research. Hydrological Processes, 22: 902-918.

428 Westhoff MC, Bogaard TA, Savenije HHG. 2010. Quantifying the effect of in-stream rock 429 clasts on the retardation of heat along a stream. Advances in Water Resources, 33: 1417-1425.

430 Westhoff MC, Gooseff MN, Bogaard TA, Savenije HHG. 2011. Quantifying hyporheic 431 exchange at high spatial resolution using natural temperature variations along a first order 432 stream. Water Resources Research, 47: W10508. 
433 Wilby RL, Johnson MF, Toone JA. 2012. The Loughborough University TEmperature

434 Network (LUTEN): Rationale and analysis of stream temperature variations. Proceedings of 435 Earth Systems Engineering 2012: Systems Engineering for Sustainable Adaptation to Global 436 Change. Newcastle, UK.

437 Wilby RL, Johnson MF, Toone JA. 2014. Nocturnal river water temperatures: Spatial and 438 temporal controls. Science of the Total Environment, 482-483: 157-173.

439 Wilby RL, Orr H, Watts G, Battarbee RW, Berry PM, Chadd R, Dugdale SJ, Dunbar 440 MJ, Elliott JA, Extence C, Hannah DM, Holmes N, Johnson AC, Knights B, Milner NJ, 441 Ormerod SJ, Solomon D, Timlett R, Whitehead PJ, Wood PJ. 2010. Evidence needed to 442 manage freshwater ecosystems in a changing climate: turning adaptation principles into 443 practice. Science of the Total Environment, 408: 4150-4164.

444 Zolezzi G, Siviglia A, Toffolon M, Maiolini B. 2011. Thermopeaking in Alpine streams: 445 event characterization and time scales. Ecohydrology, 4: 564-576. 
447 Table 1 Properties of 12 events with most rapid changes in Tw at site D10 between March 2011 and February 2014

\begin{tabular}{|c|c|c|c|c|c|c|c|c|c|c|c|c|c|}
\hline Variable & Sites & $1 / 5 / 11$ & $4 / 5 / 11$ & 4/4/12 & 6/5/12 & 28/6/12 & $5-6 / 7 / 12$ & 10/7/12 & 27/1/13 & $1 / 5 / 13$ & $2 / 5 / 13$ & $6 / 5 / 13$ & $7 / 5 / 13$ \\
\hline $\mathrm{P}_{\text {tot }}(\mathrm{mm})$ & Buxton & 0 & 0 & 8.4 & 0 & 4.7 & 11.7 & 17.3 & 0 & 0 & 0 & 0 & 0 \\
\hline $\mathrm{P}_{\text {tot }}(\mathrm{mm})$ & $\mathrm{HC}$ & 0 & 0 & 18.8 & 0 & 17.2 & 30.6 & 13.6 & 6.6 & 0 & 0 & 0 & 0 \\
\hline $\mathrm{P}_{\mathrm{tot}}(\mathrm{mm})$ & Ashbourne & 0 & 0 & 11.4 & 0 & 16.8 & 18.2 & 5.4 & 0.6 & 0 & 0 & 0 & 0 \\
\hline $\mathrm{Q}_{0}\left(\mathrm{~m}^{3} / \mathrm{s}\right)$ & $\mathrm{HC}$ & 0.071 & 0.070 & 0.093 & 0.178 & 0.278 & 0.351 & 0.330 & $0.958 \dagger$ & 0.079 & 0.076 & 0.072 & 0.069 \\
\hline $\mathrm{Q}_{0}\left(\mathrm{~m}^{3} / \mathrm{s}\right)$ & IW & 0.767 & 0.752 & 0.979 & 2.040 & 2.780 & 3.080 & 3.280 & 2.260 & 1.150 & 1.140 & 1.080 & 1.060 \\
\hline$\Delta \mathrm{Q}\left(\mathrm{m}^{3} / \mathrm{s}\right)$ & $\mathrm{HC}$ & -0.001 & -0.001 & +0.028 & 0 & +0.205 & $+11.35 \dagger$ & $+5.09 \dagger$ & $+2.63 \dagger$ & 0 & -0.002 & -0.003 & -0.001 \\
\hline$\Delta \mathrm{Q}\left(\mathrm{m}^{3} / \mathrm{s}\right)$ & IW & -0.007 & 0 & +0.421 & 0 & +1.980 & +7.12 & +3.23 & +9.44 & -0.010 & -0.020 & -0.030 & -0.020 \\
\hline Ta range $\left({ }^{\circ} \mathrm{C}\right)$ & D10 & 11.3 & 18.3 & 2.4 & 17.6 & 11.1 & 14.0 & 4.5 & 5.3 & 17.5 & 19.7 & 22.2 & 20.2 \\
\hline $\operatorname{Max} \Delta \mathrm{Tw}\left({ }^{\circ} \mathrm{C} / \mathrm{hr}\right)$ & D10 & +1.0 & +1.0 & -1.0 & +0.9 & +2.8 & +2.4 & +1.2 & -1.3 & +1.1 & +1.1 & +1.1 & +1.2 \\
\hline ROC rank & D10 & 10 & 9 & 11 & 12 & 1 & 2 & 4 & 3 & 7 & 6 & 8 & 5 \\
\hline \multirow[t]{3}{*}{$\operatorname{Max} \Delta \operatorname{Tw}\left({ }^{\circ} \mathrm{C} / \mathrm{hr}\right)$} & & +1.9 & +2.0 & -1.1 & +1.0 & +3.2 & +2.4 & +1.6 & -1.3 & +1.5 & +1.2 & +1.2 & +1.3 \\
\hline & (various) & (D20) & (D20) & (D6) & (D6) & (D11) & (D10) & (D1) & (D10) & $(\mathrm{D} 6)^{*}$ & $(\mathrm{D} 6)^{*}$ & $(\mathrm{D} 6)^{*}$ & $(\mathrm{D} 6)^{*}$ \\
\hline & D23 & +0.8 & +0.8 & -0.5 & +0.8 & +2.0 & +1.2 & +0.9 & -0.8 & +0.7 & +0.7 & +0.7 & +0.7 \\
\hline Event type & All & SH & SH & $S M$ & SH & $I R$ & $I R$ & $I R$ & $S M$ & SH & SH & SH & SH \\
\hline
\end{tabular}

448 Key: $\mathrm{P}_{\text {tot }}$ (precipitation total); $\mathrm{Q}_{0}$ (pre-event discharge); $\Delta \mathrm{Q}$ (change between pre-event and peak discharge); Ta range (diel air temperature range); Max

$449 \Delta \mathrm{Tw}$ (maximum rate of change of water temperature per hour); ROC (rate of change); SH (solar heating); SM (snowmelt or snowfall); IR (intense rainfall);

$450 *$ D6 was the most upstream site after flood damage in summer/winter 2012/13; † Values outside the range used to calibrate the gauge. 
452 Figure 1 LUTEN monitoring sites (red circles), EA gauging stations (black circles),

453 Limestone outcrop (grey shading), sandstone and mudstones areas (unshaded). D10 is the 454 reference site used to detect rapid changes in Tw across the network as a whole. Source:

455 Wilby et al. (2014).

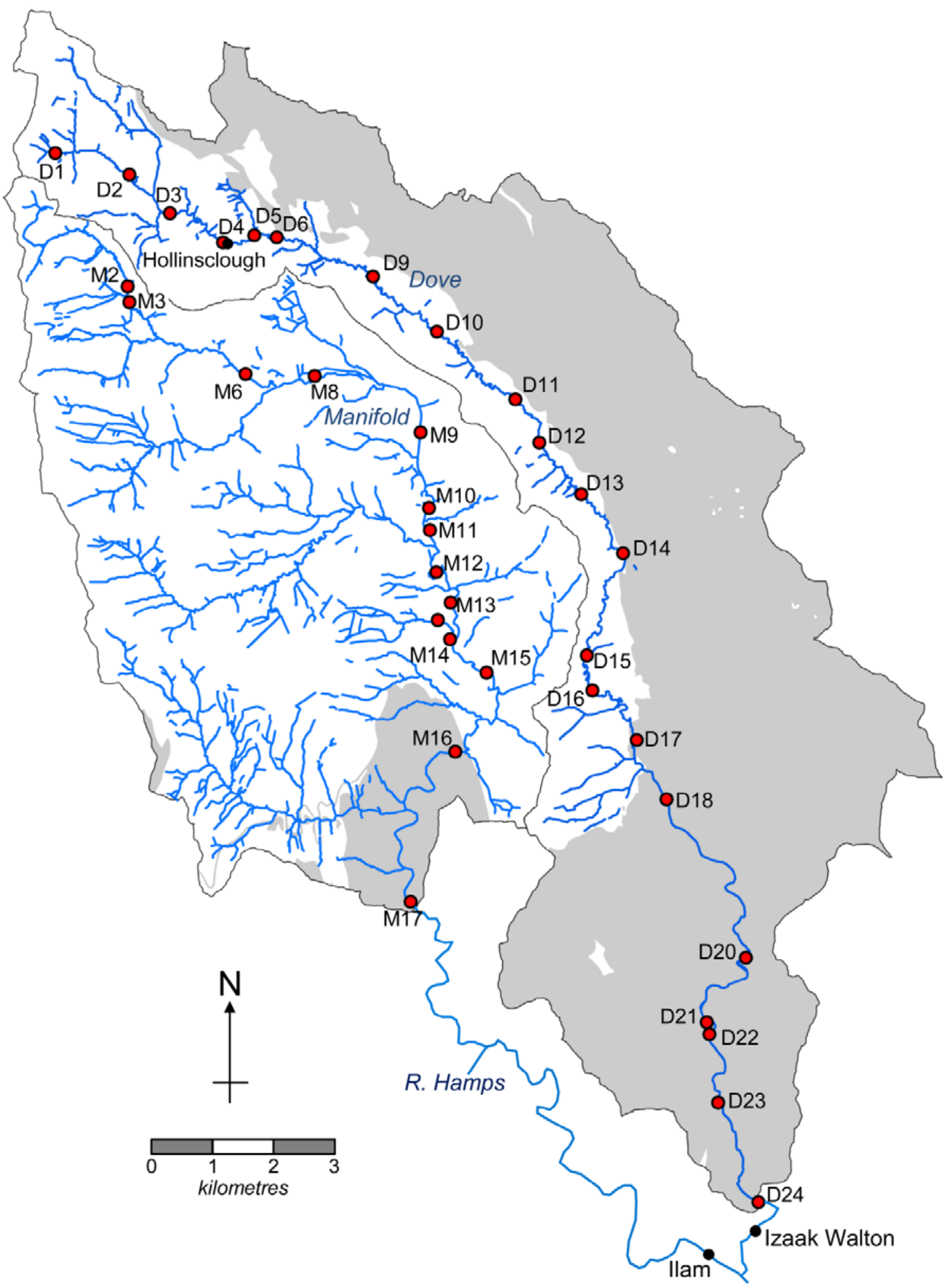


$457 \quad$ Figure 2 Example ROC series for site D10 during March 2012 to February 2013.

458

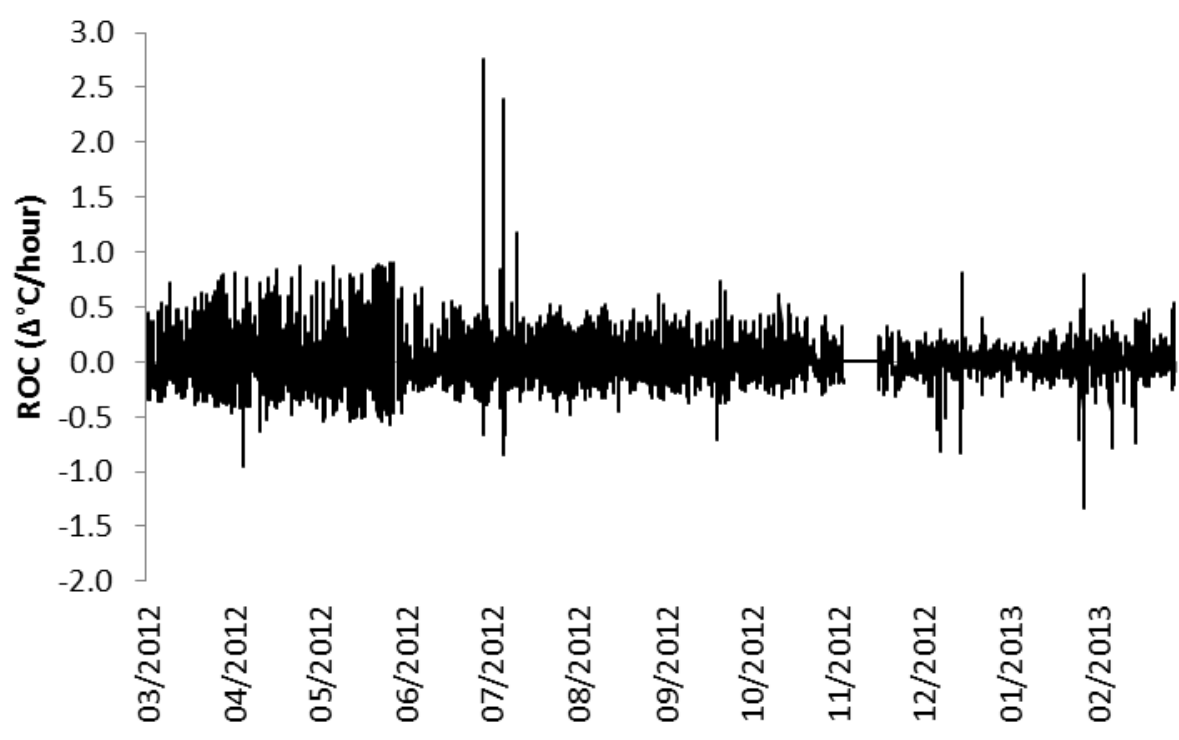

460 
461

462

463

464

Figure 3 Example thermal waves produced by a) solar heating (4 May 2011), b) snow fall (4 April 2012), c) intense rainfall (28 June 2012) d) (5-6 July 2012). A 12 degC range is used for Tw, and 20 degC range for Ta. Accompanying hydrographs and air temperatures are also shown. The river flow gauges are Hollinsclough (HC) and Izaak Walton (IW).

a)

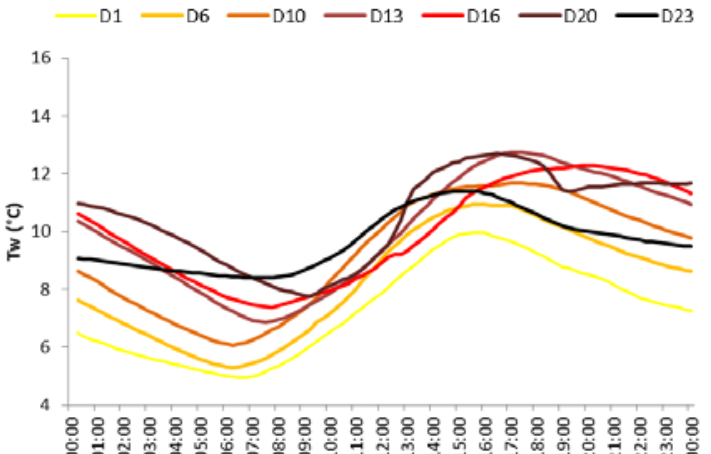

b)

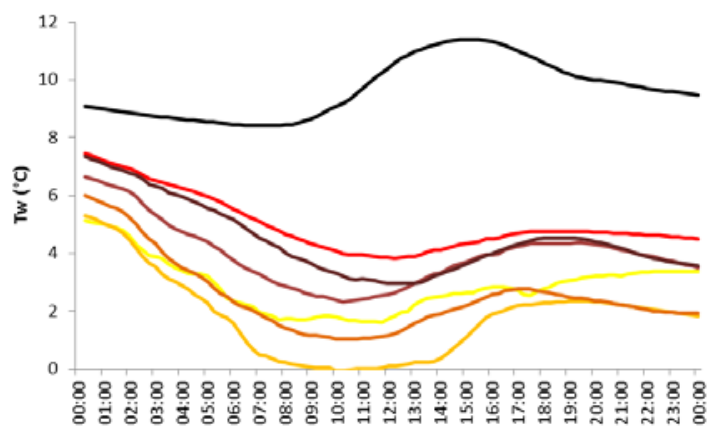

c)

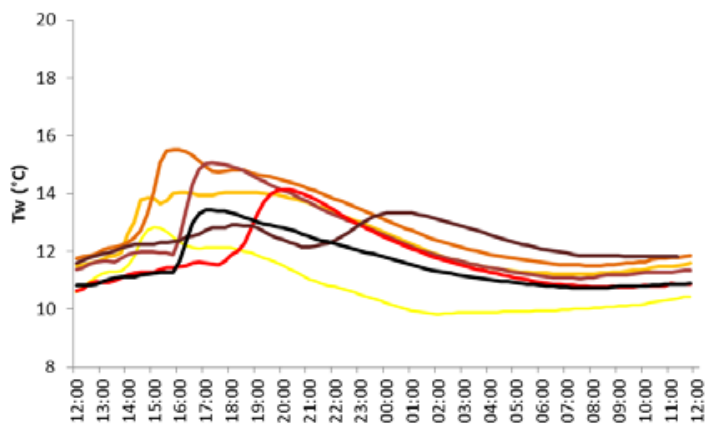

d)

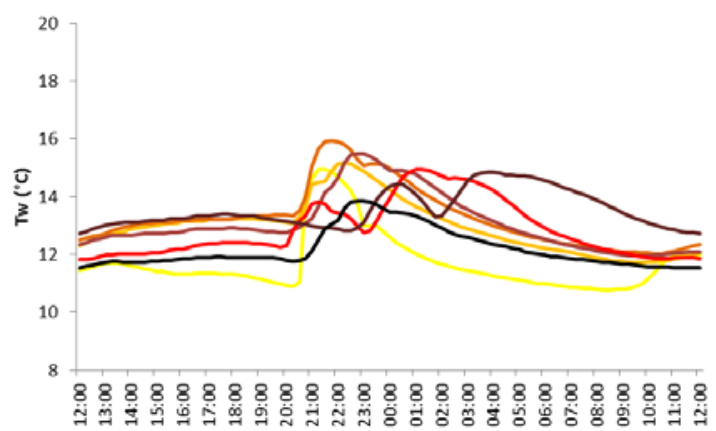

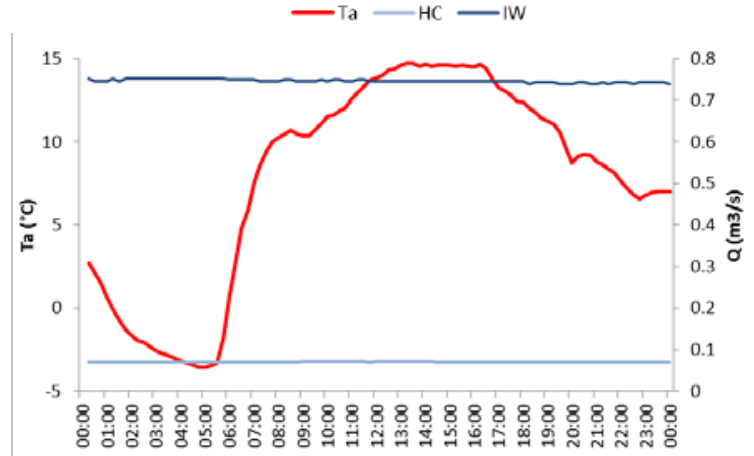
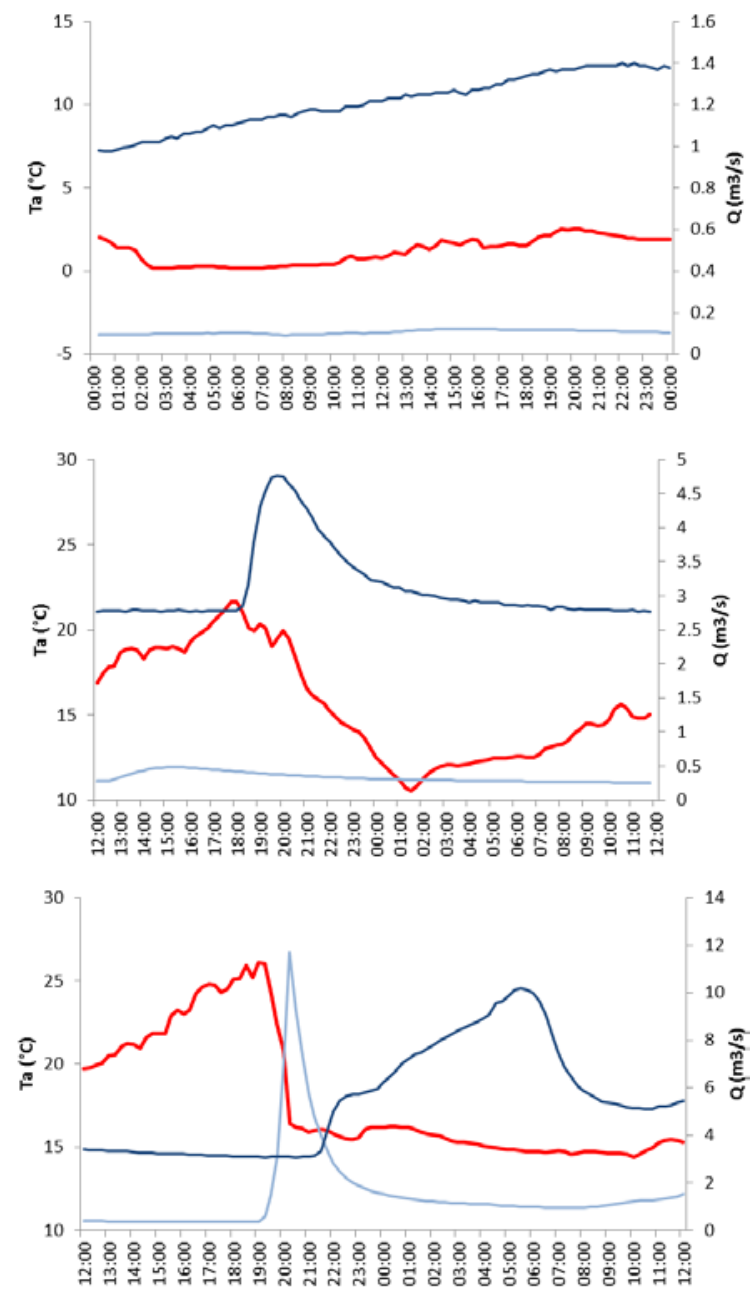

465

466 
467 Figure 4 Hourly rainfall records associated with the three IR events shown in Table 1.

468 a) 28 June 2012

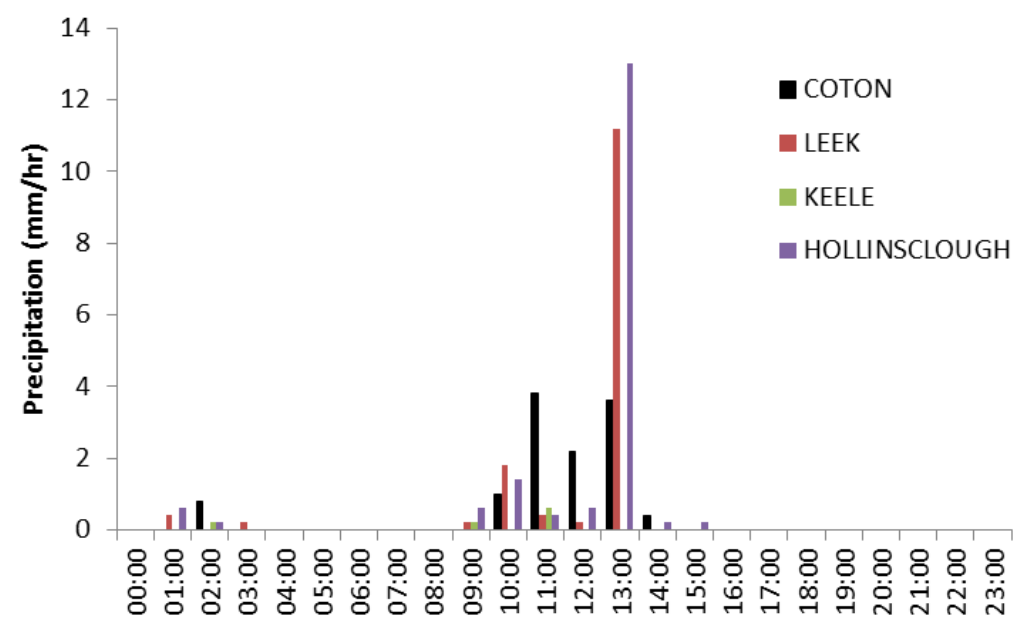

469

b) 5-6 July 2012

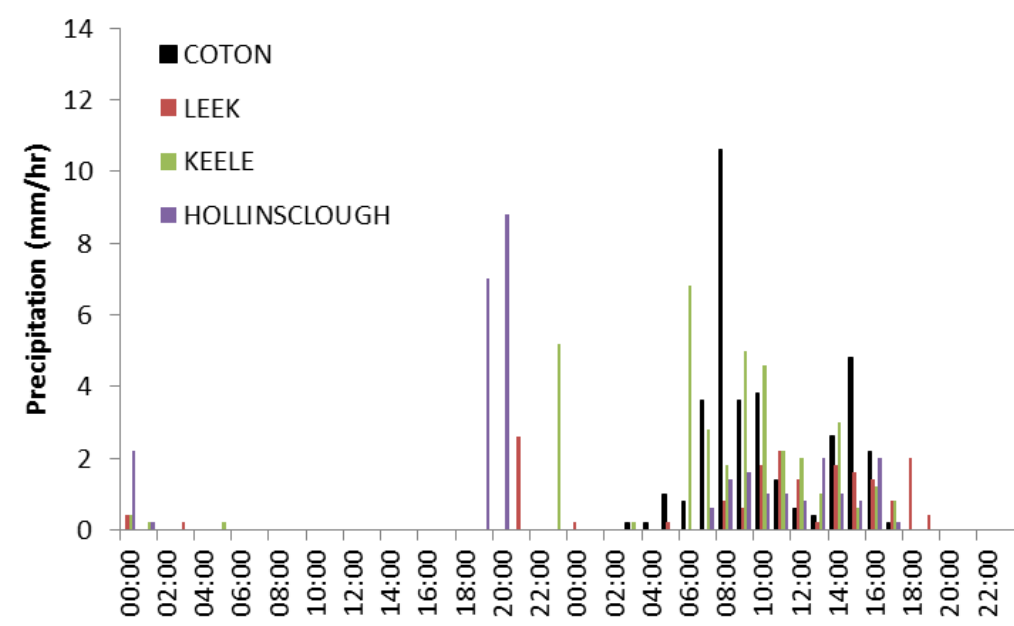

471

472 c) 10 July 2012

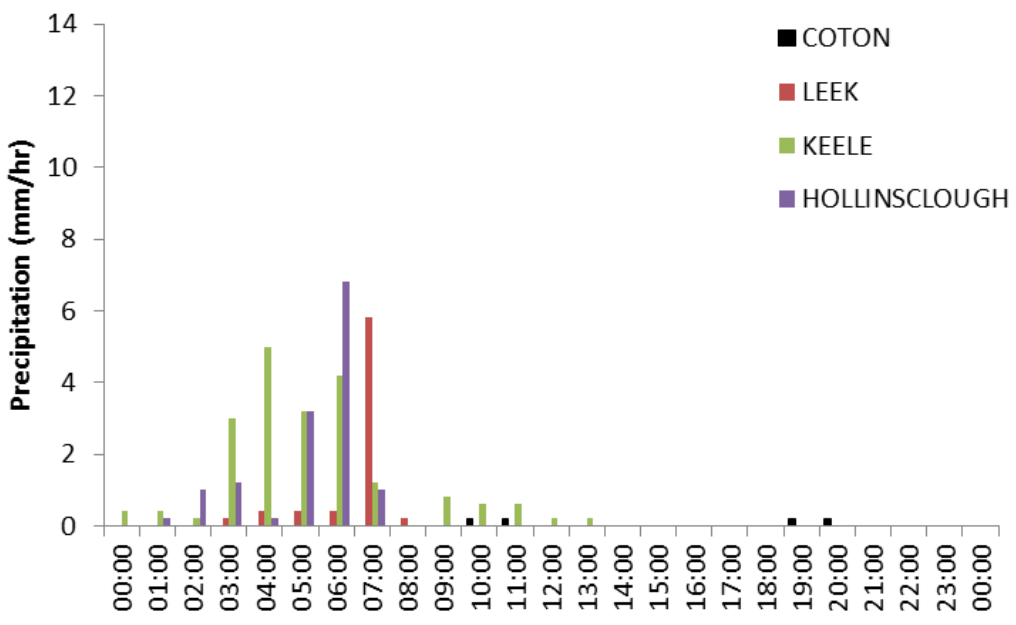


$474 \quad$ Figure 5 Times to thermo (red dots) and hydropeak (blue dots) following three intense

475 rainfall (IR) events. Note that there are less data for July 2012 because sites D15 and D17 476 were washed out by high flows in the previous month.

\section{June 2012}

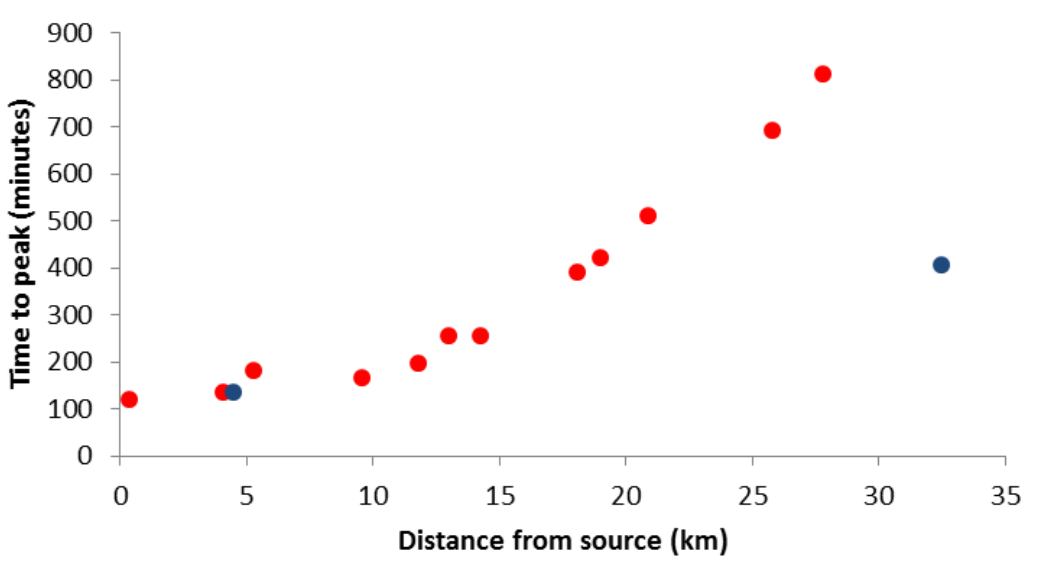

\section{5-6 July 2012}

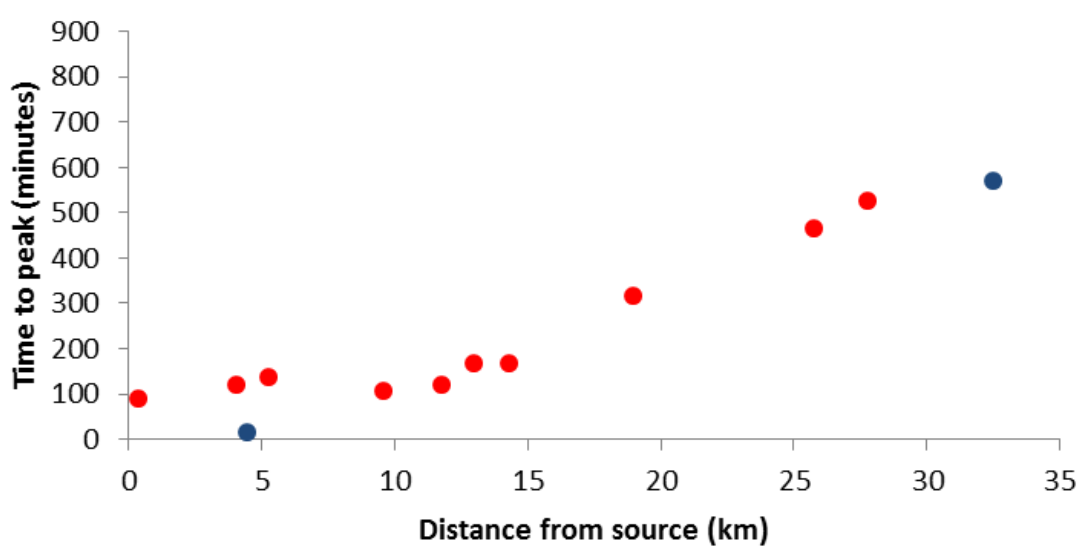

10 July 2012

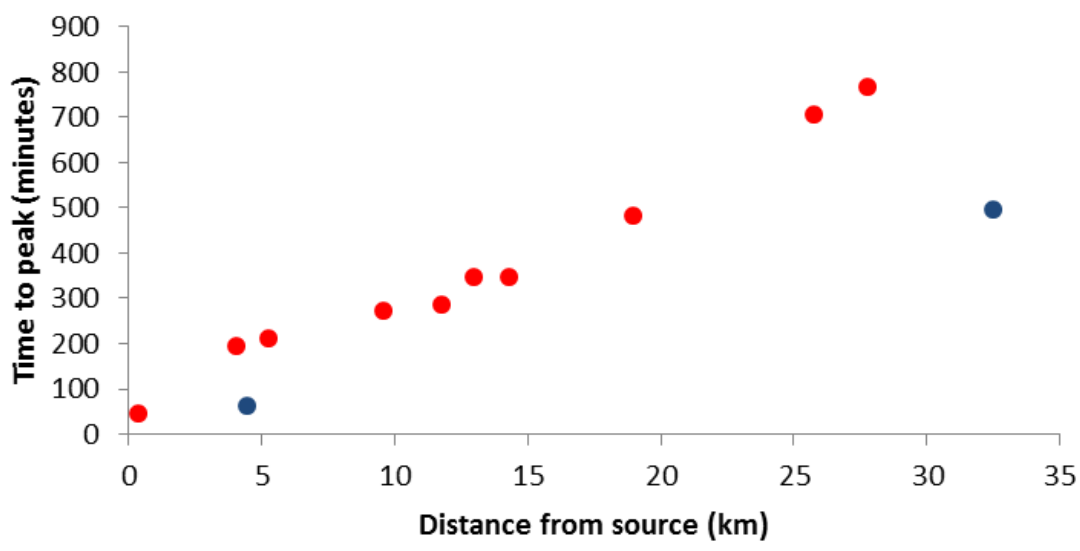


479 Figure 6 Detailed analysis of the IR thermal event of 17-19 July 2011

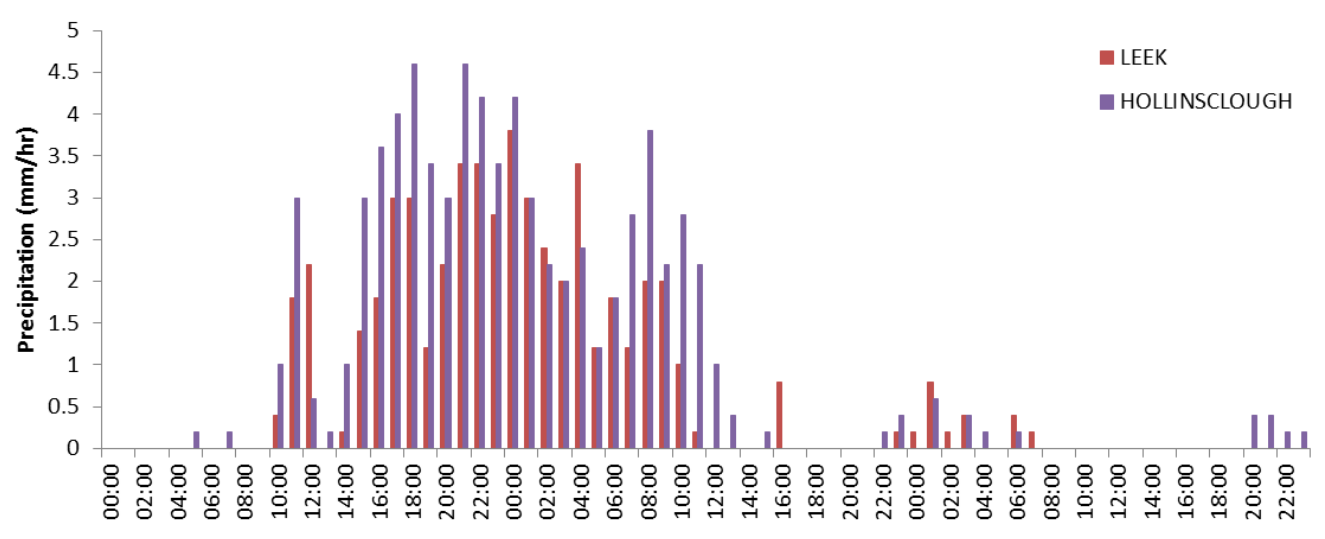

480

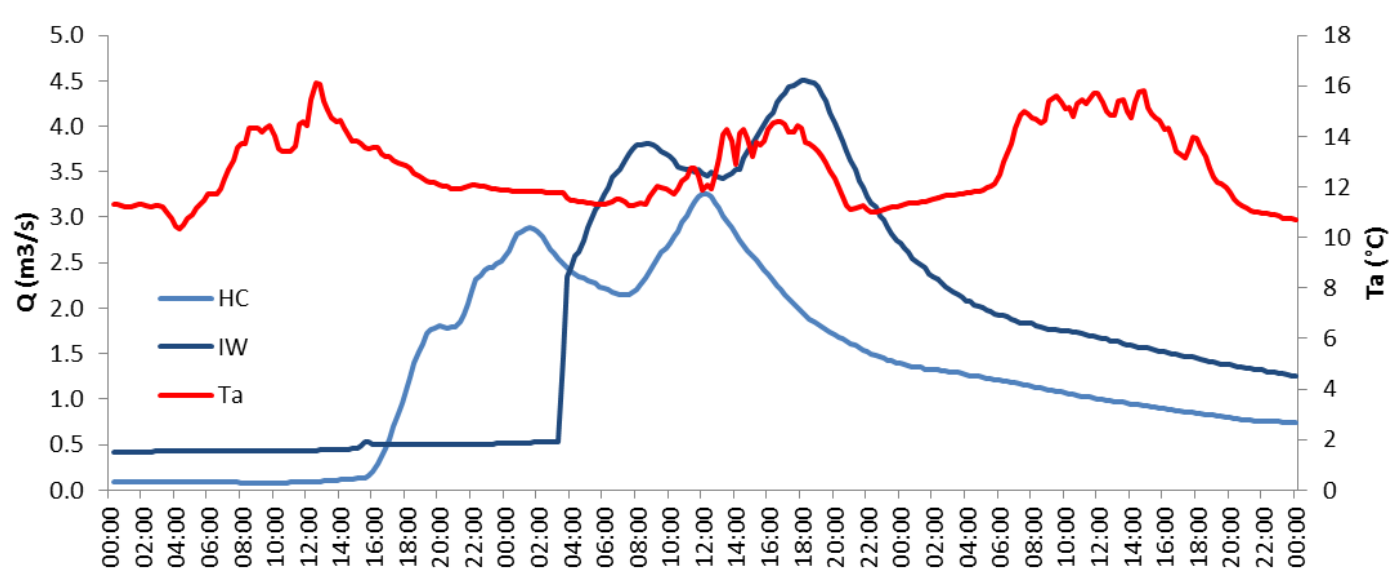

481

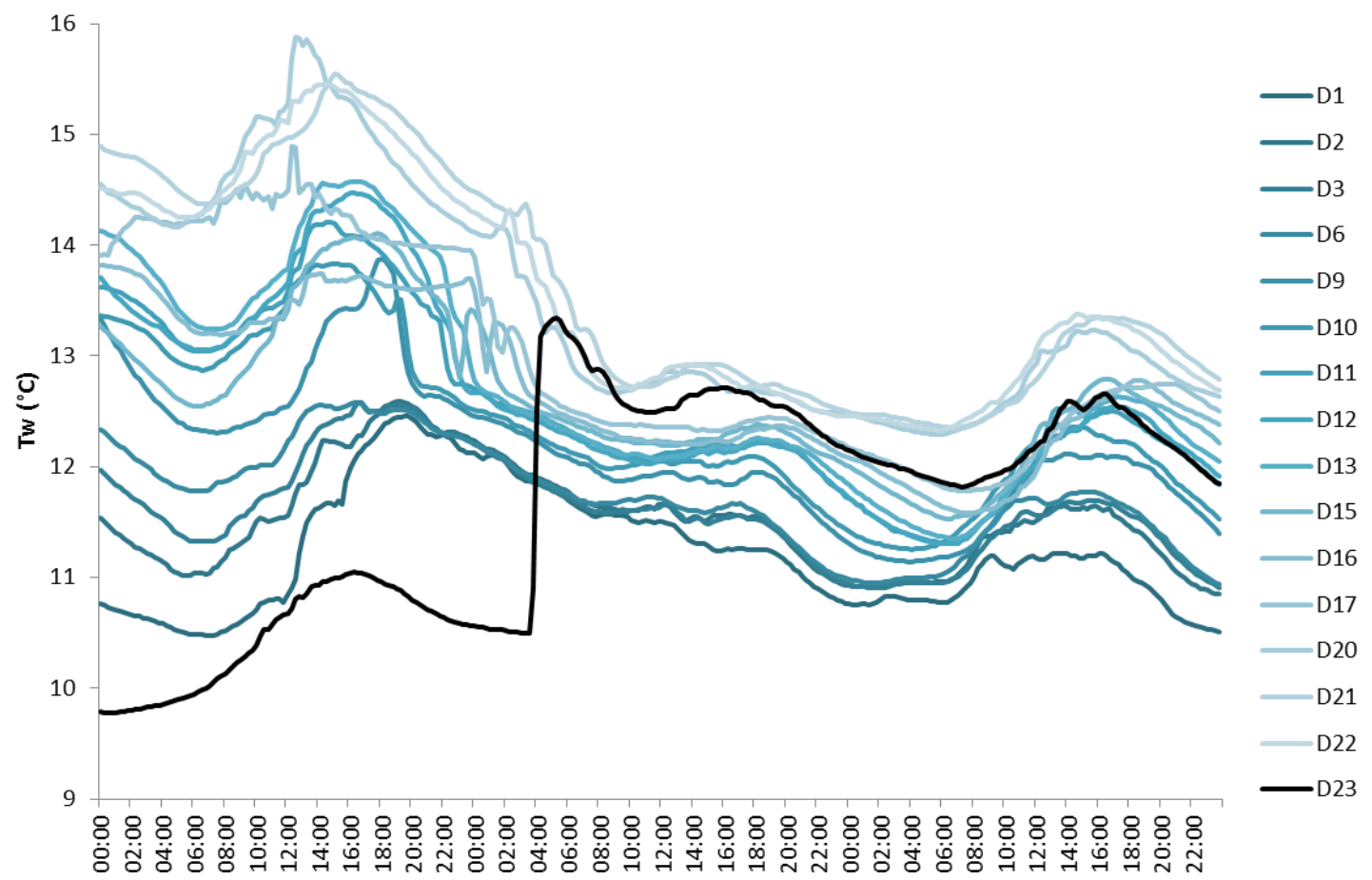

